\section{Michigan Technological 18 8 5 University}

Michigan Technological University Digital Commons @ Michigan Tech

$11-1980$

\title{
Determination of the total grain size distribution in a Vulcanian eruption column, and its implications to stratospheric aerosol perturbation
}

\author{
P. J. Murrow \\ Michigan Technological University \\ William I. Rose \\ Michigan Technological University \\ S. Self \\ NASA
}

Follow this and additional works at: https://digitalcommons.mtu.edu/geo-fp

Part of the Geology Commons, Mining Engineering Commons, and the Other Engineering Commons

\section{Recommended Citation}

Murrow, P. J., Rose, W. I., \& Self, S. (1980). Determination of the total grain size distribution in a Vulcanian eruption column, and its implications to stratospheric aerosol perturbation. Geophysical Research Letters, 7(11), 893-896. http://dx.doi.org/10.1029/GL007i011p00893

Retrieved from: https://digitalcommons.mtu.edu/geo-fp/157

Follow this and additional works at: https://digitalcommons.mtu.edu/geo-fp

Part of the Geology Commons, Mining Engineering Commons, and the Other Engineering Commons 
DETERMINATION OF THE TOTAL GRAIN SIZE DISTRIBUTION IN A VULCANIAN ERUPTION COLUMN, AND ITS IMPLICATIONS TO STRATOSPHERIC AEROSOL PERTURBATION

P. J. Murrow ${ }^{1}$ and W. I. Rose, Jr.

Department of Geology and Geological Engineering

Mich1gan Technologica1 University, Houghton, Michigan 49931

$$
\text { S. } \operatorname{se} 1 f^{2}
$$

NASA/Goddard Institute for Space Studies

2880 Broadway, New York, New York 10025

Abstract. Grain size analysis of samples representing all sampleable portions of the airfall deposit produced by the Fuego volcano in Guatemala on 14 October 1974 form the basis for est1mating the total grain size distribution of tephra from this eruption. The region enclosed by each isopach has a particular average grain size distribution which can be weighted proportionally to its percentage volume. The grain size of pyroclastic avalanche deposits produced during the eruption are also included. The total grain size distribution calculated as a sum of weighted distributions has a median grain size of $0.8 \emptyset(0.6 \mathrm{~mm})$ and a sorting coefficient $(\sigma \phi)$ of 2.3. The size distribution seems to approximate Rosin and Rammler's law of crushing and this observation allows us to estimate that no more than $15 \%$ volume of the fine tail of the total size distribution is likely to be missing. The ash composed of these fine particles did not fall in the region of the volcano as part of the recognizable tephra blanket. The eruption column reached well into the stratosphere: heights estimated from the ground were 10-12 km above sea level but estimated heights based on mass $f$ lux rates are higher $(18-23 \mathrm{~km})$. The proportion of ash smaller than $2 \mu \mathrm{m}$, which could remain for substantial periods in the stratosphere, is no more than $0.8 \%$ volume of the total. It seems probable that acid aerosol particles from vulcanian type eruptions are more important to stratospheric aerosol perturbation than fine silicate ash particles by at least an order of magnitude.

\section{Introduction}

Volume estimates of pyroclastic deposits produced by explosive volcanic eruptions based on isopach maps of the deposits yield minimum values. The reasons for this are:

1) Ash which falls beyond the most distant mapped isopach may account for a significant portion of the total volume because its aerial extent is large. However, it is not readily identiffable in the field and uncontaminated samples useful for grain size analysis are difficult to obtain.

2) The location of many volcanoes in island

$\begin{array}{ll}1_{\text {Now at: }} & \begin{array}{l}\text { Air Pollution Contro1, District Health } \\ \text { Office, Private Bag, Wellington, New } \\ \text { Zealand }\end{array} \\ 2_{\text {Now at }} & \begin{array}{l}\text { Department of Geology, Arizona State } \\ \text { University, Tempe, AZ } 85281\end{array}\end{array}$

Copyright 1980 by the American Geophysical Union. arc settings means that a substantial portion of the tephra is often deposited in water and is therefore lost to terrestrial mapping and sampling. Identification of tephra deposits in deep sea cores alds in estimating total extent of the deposits, but the thickness and grain size of deep sea ashes is often indeterminate, because the ash rarely occurs as a discrete uncontaminated layer.

3) If stratospheric injection occurs, material is temporarily lost to the stratosphere. Particles larger than $2 \mu \mathrm{m}$ precipitate out in hours to a few days (Lamb, 1970; Kasten, 1968) but may not be identifiable as part of the airfall deposit if they are widely dispersed by troposphere winds. Particles smaller than $2 \mu \mathrm{m}$ may be rained out of the troposphere in days to weeks. However, any fine material which reaches the "dry" stratosphere will have a much longer residence time and be dispersed over a very wide (global) area (e.g. McCormick and others, 1978). Vulcanian eruptions are the most frequent source of volcanogenic injections into the stratosphere and yet very little is known of the volume and number of particles which contribute to the stratospheric aerosol layer.

Our purpose was to determine the total grain size distribution produced by a typical vulcanian event.

\section{The Fuego 14 October 1974 Vulcanian Eruption}

This event was selected for study because it was a short-1ived, powerful eruption and because samples were collected over an extensive fallout area immediately after the event (before the next fall unit was deposited on 17 October) (Rose and others, 1978). Parameters such as duration of the eruption (5-17 hrs.) and the volume of ejecta produced axe available making it possible to estimate, using the model of Wilson and others (1978), that the actual column height was in the order of 18-23 km above sea level, well above the Guatemalan tropopause at that season.

\section{Method Used for Estimating Total Grain Size Distribution}

The total volume of the deposit and the volume contained within each isopach was calculated using the isopach map of Rose and others (1978, p. 10). The volume within each isopach was expressed as a percentage of the total volume (Table 1 ). Because the total grain size distribution produced by the eruption includes all pyroclastics, the material contained within the pyroclastic avalanche deposits also was included. These were estimated to comprise $10 \%$ of the total vol- 
TABLE 1. Incremental Bulk Volume* Calculations of Airfall Unit of 14 October 1974.

\begin{tabular}{clr}
\hline Isopach, $\mathrm{cm}$ & $\begin{array}{l}\text { Bulk Volume, } \\
\mathrm{km}^{3}\end{array}$ & \% of Total \\
\hline 10 & 0.0187 & 40.3 \\
5 & 0.0038 & 8.2 \\
2 & 0.0076 & 16.4 \\
1 & 0.0019 & 4.1 \\
0.5 & 0.0066 & 14.2 \\
0.3 & 0.0032 & 6.9 \\
Avalanche & $0.0046 * *$ & 10.0 \\
deposits & 0.0464 & 100.1 \\
TOTAL & 0 \\
\hline
\end{tabular}

*Bulk Volume means the volume of the deposit in the field

**Estimate of Davies et al, 1976.

ume ejected (Davies and others, 1978).

Samples were sieved down to $25 \mu \mathrm{m}$ ( $5.5 \emptyset$ or 500 mesh) by hand to minimize abrasion. Where the sample was split to facilitate sieving in the finer mesh sizes, both halves of the split were weighed and the results from the sieved split adjusted accordingly. The $<25 \mu \mathrm{m}$ fraction was examined with a Coulter Counter (see Huang and others, 1975) for all samples in which this fraction accounted for more than $5 \mathrm{wt} \%$ of the total. 4-15 samples were sieved from each of the $10 \mathrm{~cm}$, $5 \mathrm{~cm}, 2 \mathrm{~cm}, 1 \mathrm{~cm}, .5 \mathrm{~cm}$, and $.3 \mathrm{~cm}$ isopach intervals. Two samples of the pyroclastic avalanche deposits were sieved.

The average grain size distribution for each isopach interval was calculated (Figure 1).

These results were then weighted with respect to the contribution of each interval to the whole volume. The total grain size distribution (Figure 2) was derived from the sum of the weighted percentages in each size interval. The total grain stze distribution for the October 14 erup-

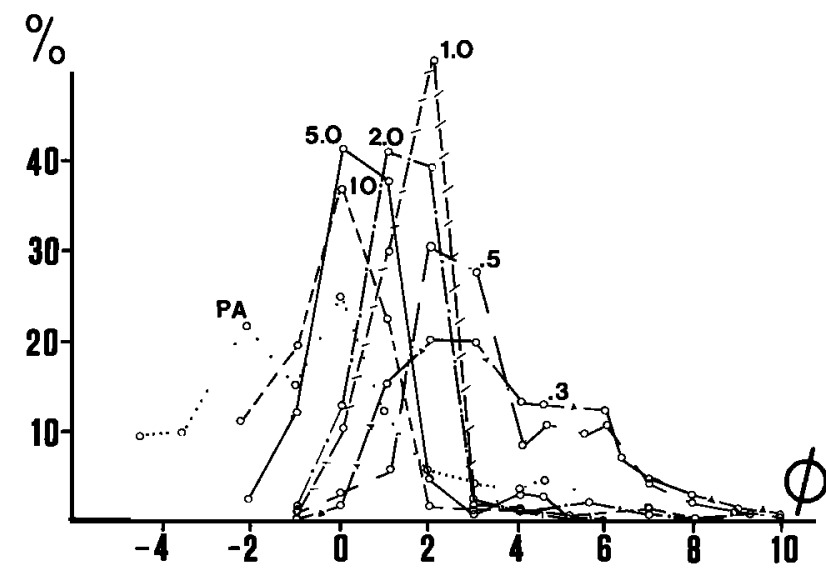

Fig. 1. Average grain size distributions of ashes from different isopach intervals of the October 14, 1974 airfall unit. The size distribution of pyroclastic avalanche is also plotted, labeled as PA. Data from Table 2 .

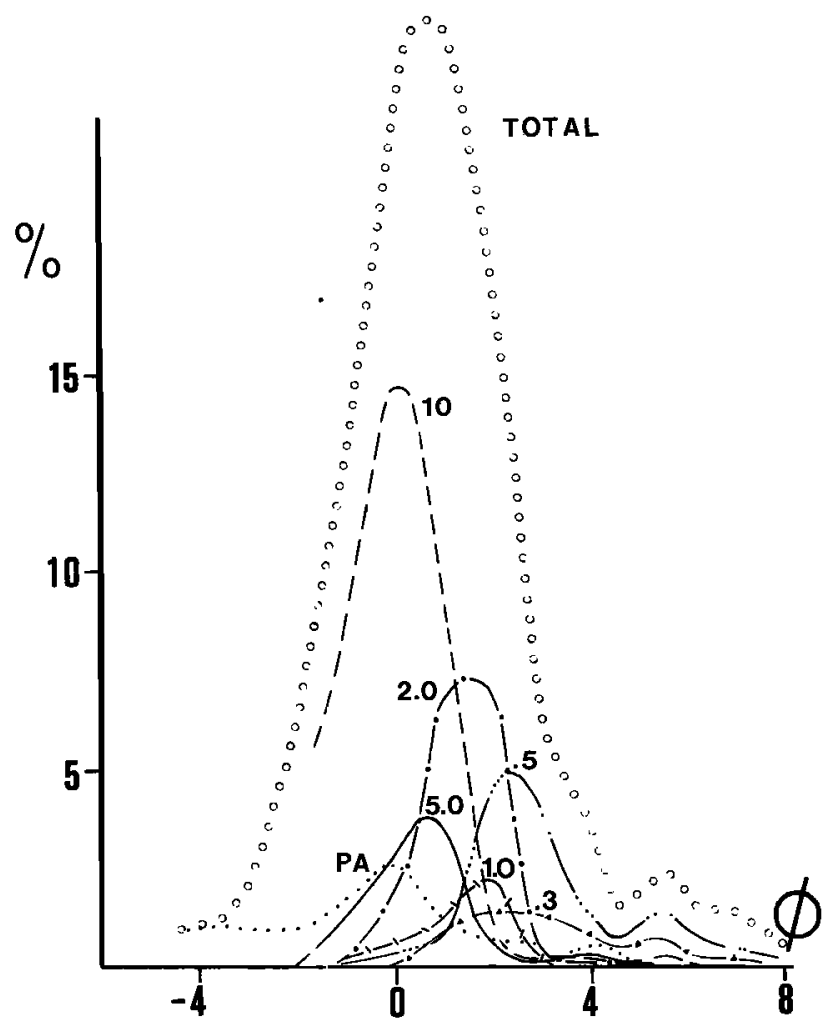

Fig. 2. Weighted average grain size distribution from different isopach intervals, according to the volume percentages represented. Data from Table 3. Upper curve is the "total grain size distribution", a summation of the others.

tion has a median diameter (Md $\emptyset)$ of $0.8 \emptyset$ and a sorting coefficient $(\sigma \phi)$ of $2.3 \phi$. These values for sorting are far higher than the typical ranges for airfall tephra $(0.25-1.00 \emptyset)$ and are almost Identical to the values obtained for the avalanche deposits (2.40). Very large blocks ( $1 \mathrm{~m}$ and greater) were ejected during this eruption. However, extrapolation of the normal curve (Fig. 2) suggests that the maximum diameter of blocks significant to the population is $0.7-1 \mathrm{~m}$.

\section{Estimation of the "Missing" Volume and Its Grain Size Distribution}

Two avenues for estimating the proportion and size of material missing from the deposit were used.

1) It was observed (Fig. 2) that the total grain size distribution for the October 14 event was essentially gaussian between -3 and $3 \emptyset$. Data from the 1978 NCAR airborne volcano cloud samp1ing project suggests that mild vulcanian eruptions produce ash particles from $1 \mathrm{~mm}$ to at least as sma11 as $0.25 \mu m$ (Rose and others, 1980a). Extrapolation of the normal gaussian curve suggest that material less than $1 \mu \mathrm{m}$ is not a volumetrically significant part of the total grain size distribution. Because no material coarser than $1 \mathrm{~mm}$ was found outside of the $0.5 \mathrm{~cm} 1 \mathrm{so}-$ pach, it is assumed that extrapolation of the fine tail of the gaussian distribution from this value $(1 \mathrm{~mm})$ following the "total" curve of Fig. 2 will give a maximum possible missing volume. 
The calculation gives a value of $.011 \mathrm{~km} 3$ or $15 \%$ of the total. Alternately extrapolation from the minor peak at $0.125 \mathrm{~mm}$ gives an estimated missing volume of $.005 \mathrm{~km}^{3}$, or $7 \%$ of the total.

2) Krumbein and Tisdel (1940) thought that many geological sediments would follow the Rosin and Rammler (1934) 1aw of crushing, however, Murai's (1961) study of pyroclastic flow and avalanche deposits from Japanese volcanoes showed that this was not the case for flow deposits. Kittleman's (1964) work is the best paper applying the Rosin-Ramnler law. Although pyroclastic flow deposits probably contain a range of grain sizes similar to the eruption as a whole, some fine material produced by the same eruption w111 be deposited as airfall tephra (Nairn and Self, 1978) and yet more will be lost by elutriation off the top of the flow as it moves downslope. The situation is further complicated by production of fine material formed by abrasion within the flow. Therefore, it is considered that a total grain size distribution including both airfall and flow deposit data may nevertheless be expressed by Rosin and Rammler's law (Fig.3).

If it is assumed that the control on the median grain size range is good, then extrapolation using Rosin and Rammler's law Into the coarse and fine fractions may indicate what proportion of the deposit is missing. Accordingly the total grain size distribution data obtained in this study was plotted on a Rosin-RammlerBennett grid and the data form a straight line in the medial grain size range $(-1$ to $3 \emptyset)$

(Fig. 3). Extrapolating the straight line above and below gives a new total grain size distribution (1.e. that which would arise if the deposit does follow Rosin and Rammler's law and if all the eruptive products were avallable for study). Comparison with the data previously obtained suggests that $.004 \mathrm{~km}^{3}$ or $6 \%$ of the total is missing from the fine fraction and $.004 \mathrm{~km}^{3}$ or $5 \%$ is missing from the coarse fraction (this being the large bombs and blocks which fell on the volcanic cone itself). It is not possible to assign accuracy to any of these estimates of missing volumes.

We feel that pyroclastic materials formed by the type of vulcanian activity exhtbited by Fuego may be produced by considerable "milling" in the vent. This may explain the good fit to Rosin and Rammler's law of crushing. Other assemblages such as those produced by plinian or strombolian activity need not conform to these laws and may be better approximated by other distribution laws.

\section{Significance for the Modelling of Stratospheric Injection}

The sizes of stratospheric volcanic silicate particles from the Agung eruption were in the range of 3 to $0.2 \mu \mathrm{m}$ (Mossop, 1964, 1965). Submicrometer particles were increasingly dominant as time passed after the eruption. Visual observations and measurements of the stratospheric aerosol layer following the Fuego eruption of October 1974 (Meinel and Meinel, 1975; Volz, 1975; McCormick and others, 1978) also suggest that particles were in the same size range.

Because only silicate material $<2 \mu \mathrm{m}$ (assuming reasonable densities of $1.00 \mathrm{~g} / \mathrm{cc}$ or more) has any long term effect on the optical thickness of

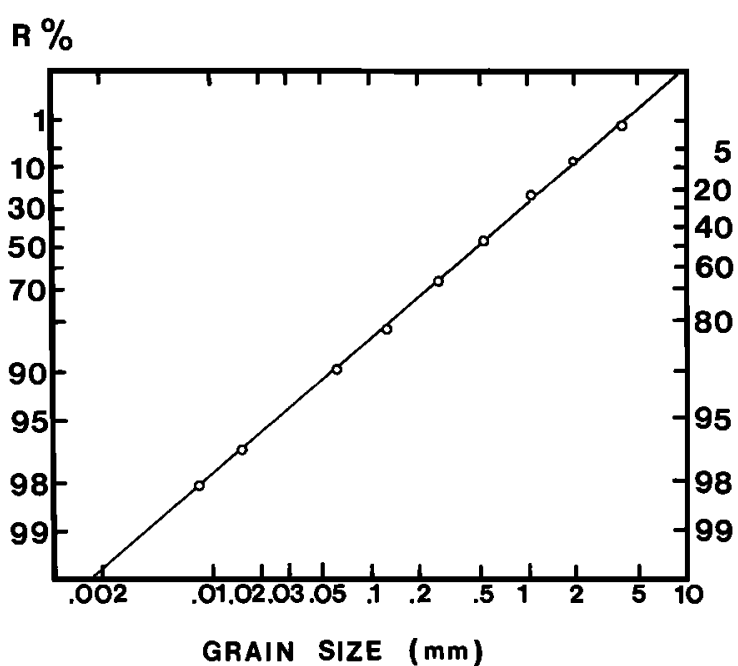

Fig. 3. Rosin-Rammler-Bennett grid on which the "total grain size distribution" is plotted. The $n$-value for the distribution shown is 0.82 . See text and Kittleman, 1964, for explanation.

the aerosol layer, the volume of material less than 2um which might be missing from the deposit was estimated by both methods. The results were $.8 \%\left(.0006 \mathrm{~km}^{3}\right)$ and $.01 \%\left(.00034 \mathrm{~km}^{3}\right)$ respectively, representing a mass in the order of $2.2 \times 10^{9} \mathrm{~g}$. Because a proportion of this material is present in deposits falling outside the determined isopachs, these can be considered as absolute maximum values for silicate material injected into the stratosphere and causing a perturbation of the optical thickness; the true values probably being considerably less. It should be noted that although the volume of material <2um injected into the stratosphere is small, the number of particles is probably significant because they may act as nucleation sites for aerosol droplets. Calculations suggest that the maximum number of sub-2 $\mu \mathrm{m}$ silicate particles injected into the stratosphere is of the order of $10^{12}$. This is a figure for the entire October 1974 eruption, an extrapolated estimate based on the detailed study of the first fall unit and its volume proportion with respect to the subsequent activity (see Rose and others, 1978).

The masses of $\mathrm{H}_{2} \mathrm{SO}_{4}$ acld droplets and $\mathrm{SO}_{2}$ (which may convert to $\mathrm{H}_{2} \mathrm{SO}_{4}$ acid particles) contributed to the atmosphere by the 1974 Fuego vulcanian eruptions (see Table 2) have been estimated by Rose and others (1980b) to be 1-2 orders of magnitude higher than masses of fine silicate particles (Table 2).

TABLE 2. 1974 Fuego Eruption: Atmospheric Impact

\begin{tabular}{lr}
\hline & $10^{12}$ particles \\
Small $(<2 \mu \mathrm{m})$ Ash & $2.2 \times 10^{9} \mathrm{~g}$. \\
Particles & $1.6 \times 10^{12} \mathrm{~g}$. \\
Gaseous $\mathrm{SO}_{2}$ & $>1.4 \times 10^{10} \mathrm{~g}$. \\
Sulfate Particles & $6.2 \times 10^{10} \mathrm{~g}$. \\
\hline
\end{tabular}

$\mathrm{SO}_{2}, \mathrm{HCl}$ and sulfate particle data from Rose et a1., 1980. 


\section{Conclusions}

Vulcanian eruptions are the most common source of volcanogenic injections into the stratosphere, yet there are scant data on the volume and number of particles that a single eruption may contribute to an aerosol layer. Calculated column heights $(18-23 \mathrm{~km})$ for the 1974 eruption far exceed the $12 \mathrm{~km}$ reports from ground observations. Sampling of the October 14, 1974 material prior to the October 17 phase gave material from a single fall unit for which a total grain size distribution has been compiled. The size distribution is more or less normally distributed about $0.8 \emptyset(0.6 \mathrm{~mm})$, and lacks a coarse tail and part of 1ts fine tail. Extrapolation of curves suggests that the maximum diameter of blocks significant to the population is $0.75-1 \mathrm{~m}$ and the minimum size is about $1 \mu \mathrm{m}$. Estimates of missing volumes based on extrapolation and the assumption that the total grain size distribution closely approximates the Rosin and Rammler law of crushing, give a best estimate of $5 \%\left(0.004 \mathrm{~km}^{3}\right)$. Of this, the volume of particles $<2 \mu \mathrm{m}$ (which may have significant stratospheric residence time) is less than $1 \%\left(5 \times 105 \mathrm{~m}^{3}\right)$. This is a maximum since a portion of these <2 $\mu m$ particles fell outside the minimum isopach. The number of particles that may have been injected into the stratosphere is also significant since they may provide sites for nucleation of aerosol droplets. Estimates suggest that the number is of the order of 1012. The total 1974 atmospheric additions of $\mathrm{SO}_{2}\left(1.6 \times 10^{12 \mathrm{~g}}\right.$ ) and $\mathrm{H}_{2} \mathrm{SO}_{4}$ droplets (>1.4 $\times 10^{10}$ g) far outweigh that of small pyroclastic particles $\left(2.2 \times 10^{9} \mathrm{~g}\right)$ partly because intrusive magma is also degassing.

Acknowledgements. Without the effort S.B. Bonis took to obtain the numerous samples of October 14, 1974 activity at Fuego, before the subsequent tephra of $17,18,19$, and 23 october fell on top of them, this study would not have been possible. Bonis' effort in October, 1974 has resulted in more than a dozen scientific papers to date.

Financial support for this work came from the National Science Foundation through grants GA 26026 and EAR 78-01190 and from NASA through grant NSG 5145 .

W. Hockings and G. Rappana provided expertise for the Coulter-Counter experiments.

\section{References}

Davies, D.K., M.W. Quearry and S.B. Bonis, Glowing avalanches from the 1974 eruption of the Volcano Fuego, Guatemala, Geol. Soc. Amer. Bu11., 89, 369-384, 1978.

Huang, T.C., N.D. Watkins, and D.M. Shaw, Atmospherically transported volcanic glass in deep sea sediments: development of a separation and counting technique, Deep Sea Research, 22, 185-196, 1975.
Kasten, F., Falling speed of aerosol particles, J. App1. Meteorology, 7, 944-947, 1968.

Kittleman, L.R., Application of Rosin's distribution in size-frequency analysis of clastic rocks, J. Sed. Pet., 34, 483-502, 1964.

Krumbein, W.C., and F.W. Tisdel, Stze distribution of source rocks of sediments, Amer. Jour. Sc1., 238, 296-305, 1940.

Lamb, H.H., Volcanic dust in the atmosphere; with a chronology and assessment of its meteorological significance, Philos. Trans. Roy. Soc. London, A-226, 425, 1970.

McCormick, M.P., T.J. Swissler, W.P. Chu and W. H. Fuller, Jr., Post volcanic stratospheric aerosol as measured by 1idar, J. Atmos Sc1., $35,1296-1303,1978$.

Meine1, A.B., and M.P. Meine1, Stratospheric dust-aerosol event of November, 1974, Science, 188, 477-478, 1975.

Mossop, S.C., Volcanic dust collected at an a1t1tude of $20 \mathrm{~km}$, Nature, 203, 824-827, 1964. , Stratospheric particles at $20 \mathrm{~km}$ altitude, Geochim. Cosmochim. Acta, 29, 201207, 1965.

Mura1, I., A study of the textural characteristics of pyroclastic flow deposits in Japan, Bull. Earthquake Res. Inst. Tokyo Univ., 39, 133-248, 1961.

Nairn, I.A., and S. Self, Explosive eruptions and pyroclastic avalanches from Ngauruhoe in February 1974, J. Volcanol. Geoth. Res., $\underline{3}$, $39-60,1978$.

Rose, W.I., Jr., A.T. Anderson, L.G. Woodruff, and S. Bonis, The October 1974 eruption of Fuego Volcano, Guatemala: description and history of the magma body, J. Volcanol. Geoth. Res., 4, 3-53, 1978.

Rose, W.I., Jr., R.L. Chuan, R.D. Cadle, and D. C. Woods, Small particles in volcanic eruption clouds, Am. Jour. Sci., 280 (in press), $1980 \mathrm{a}$.

Rose, W.I., Jr., R.E. Stolber and L.L. Malinconico, Eruptive gas compositions and fluxes of explosive volcanoes: Problems, techniques and initial data in Orogenic Andesites and Related Rocks ed. by R.S. Thorpe, Wiley \& Sons (in press), 1980b.

Rosin, P.o., and E. Rammler, Die Kornzusammensetzung des Mahlgutes im Lichte der Wahrscheinlich Keitslehre, Kolloid Zeits., 67, 16-26, 1934.

Volz, F.E., Volcanic twilights from the Fuego eruption, Sclence, 189, 48-50, 1975.

Wilson, L., R.S.J. Sparks, T.C. Huang and N.D. Watkins, The control of volcanic column helghts by eruption energetics and dynamics, J. Geophys. Res., 83, 1829-1836, 1978.

(Received May 19, 1980; accepted July 3,1980.) 